\title{
CULTURA ORGANIZACIONAL E POLÍTICAS PÚBLICAS: GESTÃo DEMOCRÁTICA DA EDUCAÇÃO EM COIMBRA, PORTUGAL
}

\author{
ORGANIZATIONAL CULTURE AND PUBLIC POLICIES: DEMOCRATIC \\ MANAGEMENT OF EDUCATION IN COIMBRA, PORTUGAL
}

Jamerson Kemps Moura ${ }^{1}$

\begin{abstract}
RESUMO
O presente artigo analisa a relação entre cultura organizacional e a apropriação de políticas públicas. Concentramo-nos nas mudanças no campo educacional da cidade de Coimbra, desde o processo de redemocratização, questionando: a cultura organizacional sedimentada nas escolas desse campo educacional poderia constituir um fator de resistência ao processo de implementação da política de gestão democrática da educação? Dentre outras constatações, destacamos que a implementação de políticas públicas tem a sua viabilização diretamente ligada às formas como ela é apropriada e dinamizada em cada cultura organizacional escolar, por isso, em Estados forjados por práticas autoritárias, o recente processo de redemocratização não conseguiu reverberar o suficiente na sociedade, fazendo com que muitos dos atores sociais não viabilizem uma gestão democrática.
\end{abstract}

Palavras-chaves: Educação; Gestão Democrática; Cultura Organizacional.

\begin{abstract}
This paper analyzes the relationship between organizational culture and the appropriation of public policies. We focus on the changes in the educational field of Coimbra city, since the process of redemocratization, questioning: the organizational culture established in the schools of this educational field could constitute a resistance factor to the process of implementing the democratic management policy of education? Among other findings, we highlight that the implementation of public policies has its viability directly linked to the ways in which it is appropriated and dynamized in each school organizational culture, so, in states forged by authoritarian practices, the recent process of redemocratization has failed to not reverberate enough in society, making many of the social actors not make democratic management viable.
\end{abstract}

Keywords: Education; Democratic Management; Organizational Culture.

\footnotetext{
${ }^{1}$ Doutorado em Sociologia pela UFPE e Doutorado Sandwich no Centro de Estudos Sociais da Universidade de Coimbra. Mestre em Antropologia e Graduado em História pela UFPE. Professor Universitário da UNIFAVIP. e-mail: kempsjamerson@gmail.com
} 


\section{Revista \\ Debates Insubmissos}

\section{INTRODUÇÃO}

O presente artigo reflete sobre a relação que se estabelece entre cultura organizacional escolar e a apropriação e viabilização de políticas públicas. Consideramos que o êxito de uma política pública também depende de como ela é dinamizada pela imbricada rede de relações que se desenvolvem entre os diversos atores do campo educacional.

Tomamos como premissa a ideia de que, mesmo em se tratando de políticas propositivas, o seu desenvolvimento também dependerá dos processos subsequentes que envolvem sua formulação e implementação. Em nossa pesquisa, concentramos nossa análise nas principais mudanças pelas quais passaram os campos educacionais do Brasil e Portugal. Para nortear nossa pesquisa, propusemo-nos a seguinte questão: a cultura organizacional sedimentada nas escolas desses dois campos poderia constituir um fator de resistência ao processo de implementação de políticas públicas?

Analisamos, então, como se deu a apropriação e viabilização da política de Gestão Democrática da Educação em escolas que compartilham culturas organizacionais advindas de práticas socioprofissionais ainda ligadas ao autoritarismo (consequência de sociedades que foram governadas por regimes autoritários) associadas a práticas socioprofissionais e novas demandas sociais oriundas de processos de redemocratização política.

Os campos educacionais por nós investigados apresentam pontos convergentes. Ambos se situam em países que implementaram políticas de gestão democrática da educação após vivenciarem regimes autoritários (o Brasil na década de 1980 e Portugal na década de 1970). Entretanto, posteriormente, esses campos educacionais cederam espaço a outras políticas de gestão escolar.

No Brasil, o processo de democratização foi incorporado ao debate educacional, mas passou por diferentes entendimentos no transcorrer do último século (WEBER, 2004). O desenvolvimento desse processo promoveu a criação de instâncias diversas - como conselhos municipais, colegiados e grupos gestores - visando a uma maior participação popular e a um maior controle e fiscalização das ações realizadas por secretarias de educação (WEBER, 1996), 
antecipando políticas que viriam a ser legitimadas pela Constituição Federal de 1998 e a Lei de Diretrizes e Bases da Educação de 1996.

A atual Secretaria de Educação determina, entretanto, que a escolha do diretor escolar só pode ser realizada após a elaboração de uma Lista Tríplice de candidatos que tenham sido aprovados em cursos de formação conduzidos exclusivamente pela Secretaria (Lei $\mathrm{n}^{\mathrm{o}}$. 13.103/2012). Assim, somente após aprovação no curso de formação (com carga horária de 180 horas) é que o candidato poderá concorrer com outros dois nomes pela preferência da comunidade escolar. Todavia, ser o candidato mais votado não garante a nomeação, pois a decisão final sobre quem será nomeado diretor caberá ao governador do Estado (grifo nosso).

Em vista da elaboração desse artigo vamos concentrar nossa análise no campo educacional da cidade de Coimbra. No que diz respeito a Portugal, destacamos que a política de Gestão Democrática da Educação também foi implementada após o fim do regime autoritário que governou o país por cinco décadas e que, assim como ocorreu no Brasil, a implementação dessa política passou por processos subsequentes, enfrentando a resistência de atores sociais forjados ou beneficiados pelas práticas anteriores.

Os processos subsequentes que inicialmente se sucederam à implementação da política de gestão democrática até que incentivavam o desenvolvimento desse tipo de gestão. Focados em desenvolver uma maior autonomia escolar, esses primeiros processos subsequentes propunham mais descentralização das estruturas, maior participação de diferentes atores sociais, elegibilidade e colegialidade.

Contudo, outros processos sucederam essa política e o sistema educacional português passou a pautar-se em uma regulação burocrática, baseada no cumprimento de normas e avaliação de resultados, dando margem à formulação e implementação da política de Agrupamento de Escolas (BARROSO, 2006). Dentre outros objetivos, essa política de agrupamentos procura reunir várias unidades de ensino em torno da administração de uma única escola-sede, desenvolvendo um espírito de concorrência e ranqueamento entre os agrupamentos e não mais estimulando a colaboração e participação entre as escolas e comunidades. 


\section{Revista \\ Debates Insubmissos}

Dessa maneira, a partir da implementação da política de gestão democrática da educação, a organização do sistema educacional português vivenciou um estágio inicial de democratização e descentralização até chegar ao atual estágio de centralização e padronização das atividades. Segundo Lima (2004, p. 22), o sistema educacional português tornou-se um "sistema centralizado-desconcentrado, onde o que é relevante é a escola-sede, mas nem tanto o agrupamento e, muito menos, as escolas que o compõem".

Diante do exposto, interessamo-nos pela análise dos processos subsequentes que envolveram a política de Gestão Democrática da Educação e as demais políticas implementadas. Levantamos, então, as seguintes questões: os objetivos da política de gestão democrática da educação foram alcançados ou os interesses políticos de atores não democráticos se sobrepuseram a eles? Haveria ainda algum ranço comportamental não democrático nas culturas organizacionais escolares dos dois campos? Tal ranço influenciaria a apropriação e viabilização das políticas de gestão democrática da educação?

\section{CONCEPÇÕES METODOLÓGICAS}

Como as organizações do campo educacional tendem a se apropriar das políticas públicas de maneiras distintas, elas não devem ser analisadas a partir de uma ótica de padronização das atividades. Uma vez que precisamos tratar de realidades, atores e interpretações distintas, entendemos que a dinâmica de funcionamento dessas organizações está sujeita aos interesses e influência de diversos agentes políticos e atores sociais.

É, pois, relevante compreender como as políticas educacionais partem do Estado e são dinamizadas pelas organizações escolares. Nesse sentido, a atuação do diretor é significativa, por ele ser um elemento intermediário entre a estrutura estatal e os indivíduos ligados à organização que dirige. Suas práticas de gestão irão interferir diretamente na implementação de políticas públicas. Ele é o único indivíduo que tem acesso constante e representativo entre dois distintos espaços de poder: o órgão administrativo estatal e a organização escolar.

Na Universidade de Coimbra, desenvolvemos uma parte do projeto de pesquisa que conciliasse a pesquisa no campo educacional como forma de dar maior consistência a nossa 
argumentação científica. A pesquisa empírica que realizamos procurou por uma interpretação compreensiva que iluminasse semelhanças e diferenças.

Por interpretação compreensiva, Roberto Cardoso Oliveira entende ser essa "a operação pela qual se reúnem dois ou mais objetos em um mesmo ato de pensamento para separar as semelhanças ou diferenças" (2006, p. 216). A partir dessa definição para o termo, contextualiza a discussão sobre o método comparativo dentro do campo acadêmico, destacando a influência negativa da ideologia colonial e eurocêntrica incorporada pela Antropologia em sua constituição como disciplina.

Com base nessas concepções, percebemos que, de forma semelhante, Brasil e Portugal representam sociedades que passaram por regimes autoritários e implementaram a política de gestão democrática da educação. Também de maneira semelhante, essa política passou por processos subsequentes nos dois campos educacionais, porém, os processos do caso brasileiro são diferentes dos processos que se sucederam no caso português, como também diferentes são as interpretações dos atores e práticas de gestão desenvolvidas em cada organização.

Inspirados pelo prof. Dr. Rui Gomes, compreendemos que a cultura organizacional escolar constitui um tipo híbrido, capaz de sofrer influência externa do sistema educacional, agentes e comunidade escolar (GOMES, 1993). Dado o intricado sistema de relações que se estabelece entre os diversos atores ligados à escola é preciso considerar o caráter de dinamicidade e sentido movente desenvolvido em cada cultura organizacional escolar.

Nesse sentido, primamos pela análise qualitativa dos dados, reconhecendo na etnografia um necessário método de investigação, pois, como nos indica Jean-Pierre Dupuis (2010, p. 247), a abordagem etnográfica constitui um "método que guia a observação e lembra a articulação necessária entre os contextos de interação social, as práticas dos atores e as significações das ações para a compreensão dos comportamentos humanos e organizacionais".

A pesquisa desenvolvida em Portugal foi realizada em três unidades de ensino de um mesmo agrupamento escolar. Os critérios de escolha dessas escolas seguiram os mesmos aplicados em Pernambuco, Brasil, ou seja, escolas públicas, que ofereciam o mesmo nível de ensino, funcionavam em tempo integral e localizavam-se em bairros geograficamente 


\section{Revista \\ Debates Insubmissos}

próximos. Ainda assim, percebemos que cada uma das escolas apresentou uma dinâmica de funcionamento singular.

Nossa inserção no campo educacional português se deu em duas unidades escolares periféricas que compunham um agrupamento de escolas na cidade de Coimbra. Só depois de termos contato e aprovação de nosso acesso a essas escolas é que conseguimos chegar à escolasede do agrupamento.

Nossa abordagem qualitativa também recorreu a entrevistas com os atores sociais que trabalhavam nas organizações dos dois campos educacionais. Definimos como comunidade a ser pesquisada em nosso trabalho o coletivo de profissionais inseridos no ambiente organizacional das escolas (diretores, professores, pedagogos e demais funcionários.

Procuramos observar como esses atores, imprescindíveis à formação da cultura organizacional escolar, dinamizavam suas relações socioprofissionais nas organizações escolares e com a comunidade escolar por eles atendida. Realizamos entrevistas semiestruturadas (BAUER, 2002), sendo dezoito no campo educacional português.

Essa estratégia de produção dos dados se coaduna com a importância de reconhecer-se a sociogênese e psicogênese dos processos sociais (ELIAS, 1997) que envolvem os indivíduos e as organizações dos dois campos educacionais. Além disso, ela também possibilitou a identificação de pressupostos básicos presentes nas culturas organizacionais escolares, em específico, as que se encontram no nível das assunções básicas, nível mais profundo e muito influente (SCHEIN, 2004).

Apresentamos questões com a expectativa de identificar, dentre outras características, como se dá a participação dos atores sobre as decisões relacionadas às dimensões de uma gestão escolar (política, pedagógica, administrativa e financeira), como se deu a participação dos atores na construção dos projetos pedagógicos e de que forma constituiu-se o conselho escolar.

A pesquisa empírica também foi importante para percebermos até que ponto a dinâmica de funcionamento das organizações escolares era orientada pelos documentos estatais e projetos pedagógicos. Interessava-nos perceber se esses projetos se apresentavam como instrumentos 
que refletiam a implementação das políticas públicas nos dois campos educacionais em observância às características de cada cultura organizacional escolar.

Esses documentos passaram por uma análise de conteúdo, na qual objetivávamos perceber se havia congruência entre o que estava contido nos documentos dos órgãos responsáveis pela educação e as formas de (re)interpretação dos atores. Correlacionamos a análise de conteúdo desses documentos com as formas de apropriação dos atores expressas em seus discursos sobre as diretrizes propostas pelas políticas públicas e projetos pedagógicos.

No intuito de identificar as variáveis sociais que influenciam os indivíduos de cada campo educacional e como elas influenciam na composição da cultura organizacional de cada escola, recorremos à aplicação de questionários. Em Portugal, o universo de profissionais é de 168 (cento e sessenta e oito), dentre os quais conseguimos aplicar 57 (cinquenta e sete) questionários. Procuramos nos valer das informações que os dados quantitativos podem apresentar no sentido de fortalecer nossa análise e argumentação.

\section{CAMPO EDUCACIONAL EM PORTUGAL E EM COIMBRA}

O campo educacional português se caracteriza por encontrar, no processo de redemocratização política do país, um marco para as mudanças no sistema educacional. Governado por um sistema ditatorial por mais de quatro décadas, Portugal associa à data de 25 de Abril de 1974 uma importante travessia para o desenvolvimento de uma sociedade democrática com desdobramentos nos sistemas de gestão do seu sistema educacional.

Se, a partir de 1974, apresenta-se em Portugal um modelo educativo emergente e influenciado pelas concepções políticas de uma gestão democrática da educação, ao longo dos processos subsequentes, esse modelo passou a ter um viés de normalização do funcionamento do seu sistema educacional, guiando-se, gradativamente, pelo tecnicismo (BARROSO, 2003).

Desde meados da década de 1980 até o início dos anos 2000, gradativamente, esse sistema educacional passa a ser incorporado pela lógica ascendente do neoliberalismo e da globalização, com os quais o viés reformista apresenta-se sob a prerrogativa dos discursos que 
versam sobre modernização e integração à União Europeia. Esse processo consolida-se no transcorrer do início do século XXI, com a chegada ao poder de grupos liberais que atribuíram ao setor educacional um caráter mercadológico e de competição (idem, p. 67).

Tal caráter de competição é avaliado pelo pesquisador Rui Gomes a partir daquilo que ele denomina de análise genealógica das circunstâncias e premissas que forjam a escola de massas no campo educacional português. Em sua revisão de literatura, Gomes percebe que há dois modelos explicativos para o fenômeno da escola de massas em Portugal, divididos entre a análise da formação do Estado e o que dá ênfase à institucionalização mundial dos sistemas de educação (GOMES, 2005).

Ainda que divididos, esses estudos enfatizam três pressupostos explicativos para o fenômeno da escola de massas: o da descontinuidade, o da recusa à existência de um mandato educativo moral baseado em princípios e aquele que aborda o caráter contingente das tecnologias políticas usadas pelos sistemas educativos.

Apesar de reconhecermos que em sua obra o autor dá mais destaque ao terceiro pressuposto apresentado, para efeito de nossa pesquisa, percebemos que o pressuposto da descontinuidade é o mais adequado ao entendimento do panorama de desdobramentos das políticas públicas educacionais em Portugal desde sua abertura política.

Para Rui Gomes, a lógica tecnicista que passa a orientar as ações do sistema educativo anseia por mais eficácia, exigindo maior profissionalização dos agentes e burocratização do sistema. Citando Boaventura de Sousa Santos e a análise que esse autor também fez sobre o sistema educacional português, Gomes destaca que o "Estado heterogêneo em Portugal forjou atores sociais capazes de aceitar e de reproduzir um modo de regulação semi-periférico" (SANTOS apud GOMES, 2005, p. 163).

Assim, o governo da educação passa a concentrar a reprodução dessa centralização por meio da relação entre funcionários-agentes do Estado e diretores escolares. Na medida em que os diretores não são escolhidos pelas comunidades escolares, mas por aqueles que ocupam cargos nas direções regionais de educação, eles não só adotam o caráter dirigista e tecnicista do 
sistema como também passam a reproduzi-lo nas relações que envolvem as organizações escolares por eles dirigidas.

Corroborando o caráter centralizador que o sistema educacional passa a aprimorar ainda mais, cabe ao diretor, agora, não só a gestão administrativa, financeira e pedagógica como também a presidência do Conselho Pedagógico, evitando que ele se sinta diminuído no exercício de sua função (GOMES, 2005).

Outro importante referencial teórico sobre o governo da educação em Portugal está nos trabalhos de João Barroso. Muitos dos seus estudos trataram dos processos de regulação que envolvem o Estado e o seu desmembramento nas organizações escolares e atores do campo, a exemplo do livro A regulação das políticas públicas de educação (2006).

Barroso propõe uma análise dos processos de regulação na educação de Portugal com base no que chama de multirregulação, ao mesmo tempo em que critica as análises sobre as formas de regulação pautadas em apenas dois eixos. Ressalta que esses eixos analisam, apenas, os modos como são produzidas e aplicadas as regras que orientam a ação dos atores bem como os modos como esses mesmos atores se apropriam delas e as transformam (idem, p. 13).

Contudo, para Barroso, nem sempre o que vai determinar a regulação será feito com base na normatização (leis, decretos, regras, reformas etc.) ou apenas no contexto sociopolítico (governos, sociedade, agentes sociais e governamentais), mas a partir dos eixos que coadunam países em processo de integração e mudança no que concerne às regulações transnacionais, nacionais e locais.

Tais processos de regulação transnacional em países como Portugal e em outros países periféricos como o Brasil se dão com base na influência forçada ou desejada, dependendo dos governantes em exercício dos seus mandatos e protagonizada pelos grandes organismos internacionais e suas cartilhas de procedimentos a serem implementados por esses países.

O Estado não se retira da educação. Ele adota um novo papel, o do Estado regulador e avaliador que define as grandes orientações e os alvos a atingir, ao mesmo tempo em que monta um sistema de monitorização e de avaliação para saber se os resultados desejados foram, ou não, alcançados. Se, por um lado, ele continua a investir uma parte considerável do seu orçamento em educação, por outro, ele abandona parcialmente a organização e a gestão cotidiana, funções que transfere para os níveis 


\section{Revista \\ Debates Insubmissos}

intermediários e locais, em parceria e concorrência com atores privados desejosos de assumirem uma parte significativa do mercado educativo (ibidem, p. 50).

Quanto à regulação nacional, Barroso enfatiza o modo como as autoridades estatais representadas pelos seus órgãos administrativos e agentes (a exemplo da Direção Regional da Educação em Coimbra) exercem a coordenação, o controle e a influência sobre o sistema educativo, "orientando através de normas, injunções e constrangimentos o contexto da ação dos diferentes atores sociais" (Idem, p. 51). Esses mecanismos já se encontram consolidados e entranhados no sistema educacional e, ao se desdobrarem em mecanismos de controle, reverberam aquilo que Barroso classifica como microrregulação local.

Processo de coordenação da ação dos atores no terreno que resulta do confronto,
interação, negociação ou compromisso de diferentes interesses, lógicas,
racionalidades e estratégias em presença, quer numa perspectiva vertical entre
administradores e administrados, quer numa perspectiva horizontal, entre os
diferentes ocupantes de um mesmo espaço de interdependência (intra e
interorganizacional) - escolas, territórios educativos, municípios, etc. (idem, p. 56).

Dessa maneira, a existência desses microespaços de regulação produz um efeito mosaico no interior do sistema educativo em Portugal, a exemplo de fragmentação do tecido social na representação de grupos políticos, partidários, econômicos, religiosos, étnicos e profissionais, dentre outros. Por consequência, na medida em que promove a diversidade, essa fragmentação também dilui a responsabilidade pela educação por parte do Estado em disputas particulares e específicas.

Assim, como se percebe tais particularidades na representação dos universos singulares de cada escola, o governo da educação, por mais centralizado e hierarquizado que seja, tem que definir novas estratégias de controle por meio da regulação autônoma. Exemplo disso é a elaboração dos currículos escolares.

De maneira geral, os currículos são definidos pelo governo central, contudo permite-se que haja alguma margem de autonomia para que as escolas possam adequar seu conteúdo e práticas. Todavia, muitas das atividades de adequação às suas realidades apresentadas pelas escolas são rejeitadas, fazendo aquelas que são aceitas possuírem apenas caráter de complementaridade. Assim, em contrapartida a essa reduzida, mas possível autonomia das escolas, as administrações central e regionais do Ministério da Educação passaram a reintroduzir sistemas de avaliação externa e interna, estendendo-os às organizações escolares. 


\section{Revista \\ Debates Insubmissos}

Barroso cita ainda como processo de entrave ao desenvolvimento da autonomia das escolas o papel de inibição causado pelas diretorias regionais de educação e as inúmeras normas e exigências impostas. Esse processo estratifica ainda mais as diferenças entre as escolas, pois apenas aquelas que possuem maiores recursos educativos e boa gestão conseguem atender às exigências, condicionando as outras a uma situação periférica.

Na medida em que as escolas foram tendo autonomia para a elaboração das suas próprias cartas escolares, identifica-se uma progressiva passagem de uma regulação da procura pela oferta a uma regulação da oferta pela procura. Como não se obriga mais que os alunos frequentem escolas do seu bairro, o critério de escolha se dá entre aquelas, principalmente por parte da classe média, que possam oferecer maior sucesso e mobilidade social (BARROSO, 2003, p. 77).

A implementação desses processos de avaliação baseados na competitividade e composição de rankings deu margem para a já existente política de agrupamento de escolas tomar uma conotação de maior centralização de suas atividades bem como de profissionalização e tecnicismo. Um exemplo disso pode ser constatado na reconfiguração do ensino secundário.

O ensino secundário ocupava uma posição muito bem definida no sistema educativo português: por um lado, o ensino liceal que permitia uma formação generalista, visando às profissões da burocracia administrativa e ao acesso ao ensino superior; e, por outro, o ensino técnico que preparava para uma atividade profissional especializada (BARROSO, 2003).

Assim e sob a influência dos processos subsequentes de mudanças administrativas e sociais, Barroso nos informa que o ensino secundário licealizou-se (tornou-se cada vez mais preparatório para o ensino superior), reduziu-se (de sete para três anos), unificou-se (ensino liceal e técnico), banalizou-se (escolarizando uma elevada taxa de alunos de mesma faixa etária) e comprimiu-se (entre um ensino básico obrigatório e um ensino superior mais massificado).

Já quanto à gestão das escolas, Barroso percebe que esse processo passa a ter ainda mais força na medida em que o sistema educacional passa a dar mais relevância às concepções de regulamentação detalhada das tarefas e dos deveres dos professores e demais cargos, ao mesmo tempo em que se acirra a tensão histórica entre as concepções de racionalidade pedagógica e racionalidade administrativa dentro do campo. 
Dessa forma, o sistema educacional reforça a imagem de ser um serviço de Estado pautado em uma gestão de tipo burocrático e sujeito a uma complexa rede de normas que reforçam a intervenção da administração central e torna o diretor um mero funcionário a serviço do governo. Até mesmo quando se considera a participação dos professores no processo de gestão, premissa de uma gestão democrática da educação, Barroso percebe que ela se dá mediante a condição de que isso apenas aconteça se ele for um serviço de Estado.

A partir disso, constata-se o reflexo da evolução desses processos sobre a designação do responsável pela gestão da escola, pois, dicotomicamente, o diretor pode ser visto como um líder representante dos professores, mas também "como diretor administrativo ou delegado do governo" (idem, 2003, p. 132). O pesquisador atenta para o fato de que o rompimento com essa concepção tecnicista incorporada pelo campo educacional português só poderá ocorrer com a introdução de concepções que incluam a participação comunitária e cidadã por meio da participação da comunidade escolar e sua representação de pais, alunos, professores e outros atores. Do contrário, a integração proposta pela gestão democrática não ocorrerá.

A autonomia, enquanto expressão da unidade social que é a escola, não pré-existe à ação dos indivíduos. A autonomia da escola é um conceito construído social e politicamente, pela interação dos diferentes atores organizacionais, numa determinada escola. Não existe autonomia decretada. O que se pode decretar são as normas e regras formais que regulam a partilha de poderes e a distribuição de competências entre os diferentes níveis de administração incluindo o estabelecimento de ensino. Essas normas podem favorecer ou comprometer a autonomia da escola, mas são, só por si, incapazes de criar ou destruir a autonomia (BARROSO, 2003, p. 143).

\subsection{Política de Gestão Democrática da Educação em Portugal}

Embora a política de Gestão Democrática da Educação também tenha sido implementada no campo educacional português, ainda como desdobramento da abertura política oriunda da simbólica data que marca o fim da ditadura (25 de abril de 1974), ela não é mais praticada em Portugal. Desde sua implementação, é compreensível que tal política tenha enfrentado resistência por parte de atores sociais forjados e beneficiados pelas anteriores práticas autoritárias.

José Alberto Correia (1999) destaca que, depois da Segunda Guerra Mundial, se em muitos países ocidentais a educação foi sendo despolitizada sob o argumento de se garantir a democracia e estabilidade política, em Portugal se deu o oposto. O movimento revolucionário 
no contexto de 1974 entendia que por meio da politização do sistema educacional é que se conseguiria garantir a manutenção e fortalecimento do sistema político implantado com base na democracia e contrário ao anterior regime ditatorial.

\begin{abstract}
A configuração das relações entre educação e democracia, ao incorporar a problemática da construção da escola democrática, não poderia, desta forma, incidir na definição do papel e da intervenção de um Estado encarado como garante da democracia a de respeito pelo princípio da 'igualdade de oportunidades'. Ao incluírem no seu campo semântico a problemática da construção da escola e da sua democracia interna, os 'discursos educativos' democratizantes tiveram de lidar com o problema da governação das escolas que, neste contexto, tende a ser dissociado da problemática da eficácia para se centrar nas indeterminações entre a vida política e a função social da escola (idem, 1999, p. 83-84).
\end{abstract}

Correia percebe que as decisões políticas advindas do Estado precisavam, antes de chegar à sociedade, passar pelas escolas. Entretanto, na medida em que essas escolas haviam sido constituídas de indivíduos forjados em uma sociedade autoritária como fora Portugal até então, era de se esperar que os preceitos de uma escola democrática não fossem incorporados.

Assim, a dinâmica interna das escolas se via diante da necessidade de, a partir do desenvolvimento do debate sobre democracia e educação, garantir não só a sustentabilidade do governo e sistema educativo como também o acesso universal à educação. Cabia, então, desenvolver a educação local, de base, com o propósito de constituir "comunidades e cidades locais em busca da sua emancipação" (idem, p. 85).

Como já destacamos, as políticas públicas desse campo conviveram com processos subsequentes à sua implementação. No caso da política de gestão democrática da educação, ela pode ser analisada a partir da promulgação de quatro leis estatais em períodos distintos.

Em síntese, a primeira lei incentivou a descentralização das estruturas e princípios educativos, enquanto a segunda aperfeiçoou esse processo, possibilitando maior participação, elegibilidade e colegialidade. Porém, as duas leis seguintes caracterizam-se por determinações que se associam à descontinuidade e a mudanças políticas e ideológicas, e imprimem à gestão das escolas um caráter de maior racionalização, verticalidade e centralização.

O primeiro e o segundo momentos são congruentes e têm como referência a Lei $n^{o}$. 46/86, de 14 de outubro de 1986 e o Decreto-Lei n'. 115-A/98, de 4 de maio de 1998. A primeira lei incentivou a descentralização das estruturas e princípios educativos, tornando as escolas e 
suas gestões mais autônomas. Por sua vez, a segunda lei aperfeiçoou esse processo de descentralização, promovendo medidas que estimularam maior participação, elegibilidade e colegialidade. Essas orientações possibilitaram que as escolas se agrupassem de acordo com os seus interesses, afinidades e proximidade geográfica.

\begin{abstract}
Os agrupamentos deveriam garantir um percurso sequencial e articulado dos alunos, superando a situação de isolamento geográfico e socioeconômico das escolas, garantindo a unidade e organização pedagógica de acordo com a cultura profissional e organizacional das localidades. Seus projetos educativos deveriam representar um processo dinâmico e criativo conduzidos pelas próprias escolas e de acordo com a sua situação específica (ALMEIDA, 2010, p. 11).
\end{abstract}

Observemos que a política em questão fora formulada com caráter propositivo, procurando, dentre outros, garantir o fim do isolamento de muitas escolas e alunos que se encontravam à margem do campo socioeducacional. Contudo, percebemos que, se a partir da reabertura política foram incorporadas à educação concepções associadas à democracia bem como à participação de diferentes atores sociais e maior autonomia das escolas, gradativamente, essas concepções foram sendo superadas. A política educacional vigente é a de Agrupamento de Escolas, política sobre a qual nos debruçaremos no próximo tópico.

\title{
3.2 Política de Agrupamento de Escolas
}

O sistema educacional português deixou de nortear-se por uma regulação burocrática, adotando uma regulação de caráter produtivista baseada na avaliação dos resultados. Essa mudança, inclusive, apresenta-se como exemplo de processo subsequente à implementação de políticas públicas, dando margem à implementação da política de Agrupamento de Escolas.

Dentre outros objetivos, essa política procura reunir várias unidades de ensino em torno da administração de uma escola-sede, desenvolvendo um espírito de concorrência e ranqueamento entre os agrupamentos - reflexo de um contexto de globalização da escola de massas (GOMES, 2001).

A partir da análise de conteúdo que realizamos sobre os documentos oficiais do governo da educação em Portugal, verificamos que os processos de mudança relativos a essa política podem ser entendidos a partir de quatro leis tidas como essenciais, das quais as duas primeiras 
já foram apresentadas no tópico anterior. Todavia, para termos uma melhor compreensão da relação dessa política com as culturas escolares apresentaremos as duas leis subsequentes.

Voltamos nossa atenção agora, aos outros dois momentos-chave, os quais também representam processos de mudanças políticas e ideológicas e são representados pelo Despacho $n^{o}$. 13.313, de 8 de julho de 2003 e pelo Decreto-Lei $n^{o}$. 75/2008, de 22 de abril de 2008. O primeiro documento (e terceiro processo subsequente) caracteriza-se pela sua lógica de maior verticalidade e centralização, pois, se antes as escolas podiam se organizar em agrupamentos horizontais, nos quais era possível, por exemplo, agrupar-se com escolas de mesmo perfil socioprofissional, de mesma oferta de ciclo educacional ou de similar localização geográfica, agora são obrigadas a se agruparem segundo a lógica de racionalização e centralização.

A defesa da gestão governamental era a de que, na medida em que quase 14 (quatorze) mil escolas se reúnem em cerca de 800 (oitocentos) agrupamentos, mais eficiente se tornaria a relação dessas escolas com o Estado. Esse argumento, por sua vez, é contrariado pelos estudiosos do campo, conforme podemos constatar na seguinte colocação:

Com a extinção dos agrupamentos horizontais, o governo condicionou os atores escolares à relação entre organizações periféricas com outras organizações periféricas que intermediam a relação com o Estado, mas não sem condicioná-las ainda mais à posição de meros executores devidamente vigiados (LIMA, 2004).

Para Licínio Lima, o que houve de fato foi uma recentralização do poder, devido à qual cada escola, por meio de sua escola-sede, passou a ser apenas mais uma instância periférica de controle, o que não corresponde ao argumento estatal de evitar-se o desperdício de dinheiro e de promover-se uma maior modernização e profissionalismo no campo educacional. A lógica dos agrupamentos é, na verdade, a constituição de um "sistema centralizado-desconcentrado, onde o que seria relevante seria a escola-sede, mas nem tanto o agrupamento e, muito menos, as escolas que o compõem" (id., p. 22).

Como desdobramento do processo, o quarto e último momento-chave é representado por um documento apresentado pelo Estado como revisionista (PORTUGAL, 2008). Esse documento, além de centralizar ainda mais o governo da educação em Portugal (GOMES, 2005), impõe às escolas um caráter limitado de prestação de contas. Ainda nos primeiros 
parágrafos do documento, há várias referências às ideias de revisão, alteração e mudança relativas ao entendimento sobre o que se deveria entender como autonomia da educação.

Para tanto, institui-se o Conselho Geral, ou Órgão Colegial de Direção, responsável pelo regulamento interno, projeto educativo, plano e relatório anual de atividades, ao mesmo tempo em que a Assembleia Geral é extinta, a qual, por sua vez, caracterizava-se como mais ampla e participativa, na medida em que abarcava uma maior variedade de atores sociais. Destacamos que o novo órgão tem a "capacidade de eleger e destituir o diretor, que, por conseguinte lhe tem que prestar contas" (PORTUGAL, 2008, p. 22).

Cabe ao diretor não só a gestão administrativa como também a presidência do Conselho Pedagógico, evitando que ele se sinta diminuído no exercício de sua função, objetivando-se "reforçar a liderança da escola e de conferir maior eficácia, mas também mais responsabilidade ao diretor, é-lhe conferido o poder de designar os responsáveis pelos departamentos curriculares, principais estruturas de coordenação e supervisão pedagógica" (idem, ibidem).

O documento ainda alerta para o fato de que a tão ansiada "maior autonomia escolar deve corresponder a uma maior responsabilidade" (idem, ibidem), principalmente no que se refere à prestação de contas. Esta, por sua vez, deve organizar-se, por um lado, a partir da participação da comunidade no órgão de direção estratégica e, por outro, por meio da escolha do diretor e da adequação a sistemas de avaliação próprios e externos.

Segundo esse Decreto-Lei, a autonomia deve exprimir-se na faculdade de autoorganização da escola, com a possibilidade de criar estruturas e de fazê-las representar no conselho pedagógico. Contudo, como pudemos perceber, esse conselho deve ser composto por um número limitado de membros, além de ser obrigatório que cada escola crie estruturas de coordenação de $1^{\circ}$ nível (departamentos curriculares), conselhos e diretores de turmas. Dessa maneira, parece-nos evidente que a política pública de agrupamento escolar coloca em xeque a autonomia de uma gestão democrática. 


\section{ESTADO, ORGANIZAÇÕES E ATORES SOCIAIS}

Apresentamos agora uma análise de conteúdo dos documentos de órgãos estatais responsáveis pela educação nos dois campos educacionais e dos projetos pedagógicos das escolas pesquisadas. Esses documentos constituem elos da relação interdependente (ELIAS, 1994) entre as determinações estatais e as formas de apropriação e práticas profissionais.

Em relação aos documentos estatais, analisamos o que eles determinam, a partir da implementação de políticas públicas, que deve ser praticado nas escolas e que relevância é dada à identificação das características da cultura organizacional de cada escola. No que diz respeito à análise dos projetos pedagógicos, identificamos como eles se referem às políticas públicas e correlacionam-nas com as características da própria cultura organizacional.

Associaremos a análise de conteúdo à análise de discurso dos atores, enfocando as suas (re)interpretações sobre as determinações estatais. Para isso, questionamos: esses documentos são bem compreendidos ou há ruídos na comunicação entre os órgãos de educação e as escolas que fazem as determinações não serem apropriadas pelas culturas organizacionais da maneira pretendida pelas políticas públicas?

\subsection{Direção Regional de Ensino}

Realizamos nossa pesquisa empírica no campo educacional português na Universidade de Coimbra. Como já dissemos ao longo deste artigo, a política de Gestão Democrática da Educação passou por processos subsequentes que levaram à implementação da política de Agrupamento de Escolas.

Registramos também que essa política procura administrar várias unidades de ensino em torno de uma escola-sede, desenvolvendo um espírito de concorrência e ranqueamento entre os agrupamentos, reflexo de um contexto de globalização da escola de massas (GOMES, 2001). A partir da revisão de literatura bem como da análise de conteúdo de documentos estatais e prospecções no campo educacional, confirmamos quão seria relevante pesquisar os processos subsequentes que envolvem essas políticas e a relação delas com as culturas escolares. 


\section{Revista \\ Debates Insubmissos}

A pesquisa empírica precisou ter seu cronograma de atividades modificado por conta das dificuldades de acesso à rede de escolas e órgão educacional local. Diante das exigências burocráticas impostas pela Direção Regional da Educação em Coimbra (DREC) para a realização de pesquisas em escolas e do curto período que tínhamos para realiza-la (nove meses), ajustamos o nosso cronograma de atividades.

Nossa pesquisa partiu de uma escola periférica do agrupamento para que, assim, chegássemos à escola-sede, centro do agrupamento. De toda forma, conseguimos ter acesso a documentos estatais oriundos da DREC, em cuja análise de conteúdo destacaremos o DecretoLei $n^{0} 75 / 2008$, do Ministério da Educação.

Muitos dos referenciais teóricos do campo apresentam as direções regionais de educação como espaços nos quais se podem identificar lógicas de ação e dispositivos organizacionais que se desenvolvem a partir de regras produzidas pelo Estado. Essas regras são normas de constrangimento e dispositivos forjados com base em relações contratuais.

A DRE apresenta-se como espaço de ação situado no plano intermédio da regulação da educação, onde se concretizam as interações que veiculam os dois modos de regulação providentes de outras instâncias de regulação: no nível macro, a política educativa e a administração central, e no nível micro, a gestão escolar e administração local (AFONSO, 2006, p. 73).

As Direções Regionais de Educação encontram-se espalhadas em várias áreas do país e são tidas como mecanismos de descentralização da administração estatal. Segundo o DecretoLei ${ }^{0}$ 141/1993, as Direções Regionais de Educação (DREs) devem se caracterizar como serviços regionais do Ministério da Educação, dotados de autonomia administrativa, que asseguram a orientação, coordenação e apoio às escolas de ensino não superior.

Todavia, o que encontramos na literatura pertinente ao assunto é a constatação de que, mesmo com a distribuição das DREs, a estrutura do governo da educação em Portugal mantémse centralizada. João Barroso (2006) e Rui Gomes (2005), por exemplo, percebem que a administração do campo educacional português configura-se como centralizadora das organizações escolares por intermédio das DREs. Segundo Gomes, "a lógica técnicooperacional que preside o estilo de funcionamento das DREs é tanto mais eficaz quanto maior for a burocratização do sistema" (idem, p. 163). 


\section{Revista \\ Debates Insubmissos}

No que diz respeito à prática profissional, por exemplo, Natércio Afonso (2006) percebe que a DRE é considerada um local de passagem e aprendizado, pois muitos dos seus integrantes são docentes deslocados para aquele local de trabalho. Essa transferência se dá por influência política, não havendo uma maior preocupação sobre a competência dos profissionais para o desempenho das funções administrativas, por parte do Estado.

Assim, a consequente alta rotatividade de funcionários nas DREs serve a interesses políticos, forjando uma prática burocrática caracterizada pela captura e colonização da burocracia educacional adequada à cultura de atendimentos de demandas que privilegiam os interesses do professorado.

Essa cultura também caracteriza a dimensão das relações de trabalho. Uma vez que a burocracia é composta por membros de uma mesma categoria, a docente, evita-se um padrão de diferenciação hierárquica comum às burocracias clássicas de tipo ideal weberiano.

Seguindo essa lógica de organização, Afonso percebe que a constituição do quadro organizacional também influencia a caracterização da dimensão política. A Direção Regional de Educação de Coimbra, por exemplo, enquanto organização burocrática e de perfil profissional homogêneo, limita suas práticas cotidianas à execução de registros técnicos e relativos às demandas externas, não havendo preocupação em desenvolver um planejamento de atividades de longo prazo que possa ser implementado no sistema educacional local. Afonso afirma que a imagem da DREC é a de "um serviço de natureza eminentemente executiva, com a função de assegurar a administração corrente do sistema educativo, numa lógica de complementaridade em relação a outros serviços da administração central” (id., p. 88).

A DREC se encontra dividida entre o papel de impor a obediência às normas e o papel de órgão que orienta as atividades dos profissionais da educação. Seu funcionamento é influenciado pela dificuldade em definir o que é competência dos serviços centrais do governo da educação e o que é competência das direções regionais. Enquanto espaço de mediação e de influência recíproca, na DREC se estabelece uma lógica de transação afetada pelas políticas do Estado bem como pela resolução dos problemas particulares que envolvem cada escola. 


\section{Revista \\ Debates Insubmissos}

Ao analisarmos o Decreto-Lei $n^{0} 75 / 2008$, percebemos que ele se encontra registrado no Diário da República, 1. ${ }^{\text {a }}$ Série $-\mathrm{N}^{\mathrm{o}} 79$, de 22 de abril de 2008, e apresenta as coordenadas definidoras e balizadoras da política de agrupamento de escolas. A justificava para elaboração desse Decreto destaca a importância do papel que as escolas desempenham na sociedade enquanto serviço público e, por isso,

[...] necessita de revisão do regime jurídico da autonomia, administração e gestão das escolas no sentido do reforço da participação das famílias e comunidades na direção estratégica dos estabelecimentos de ensino e no fornecimento da constituição de lideranças fortes (PORTUGAL, 2008, p. 2341).

Ainda no início do documento, encontramos várias passagens que se referem às ideias de revisão, alteração e mudança (grifo nosso) sobre o que se entendia por autonomia (destacamos ser esse um dos princípios mais importantes de uma gestão democrática da educação) e sobre o que se deve entender a partir do decreto.

O prosseguimento deste caminho exige, agora, a passagem a outro patamar, que implica a introdução de alterações ao regime jurídico de autonomia, administração e gestão escolar, de acordo com as necessidades identificadas e os objetivos definidos no programa de governo (idem, p. 2342).

O documento é recheado de revisões conceituais sobre o que se deve entender por autonomia. Exemplo disso é a ênfase do Decreto ao fato de que, paralelamente ao discurso de abertura da escola à comunidade local (outro importante princípio de uma gestão democrática da educação), deve haver a preocupação com a necessidade de prestação de contas da escola "àqueles que ela serve" (idem, ibidem).

Nesse sentido, o Decreto determina a criação do Órgão Colegial de Direcção, responsável pelo Regulamento Interno, Projeto Educativo, Plano de Atividades e Relatório Anual de Atividades, em substituição à Assembleia Geral (grifo nosso). Mesmo antes de destacarmos a ausência de qualquer referência ao conceito de gestão democrática da educação e valorização das culturas organizacionais escolares nesse documento, grifamos o trecho em que se delibera a extinção da Assembleia Geral. No lugar desse órgão importante para uma gestão democrática, se estabelece um organismo mais centralizador: o Órgão Colegial de Direção. No documento, destaca-se o fato de esse órgão ter a "capacidade de eleger e destituir o diretor, que, por conseguinte, lhe tem que prestar contas" (idem, ibidem). 


\section{Revista \\ Debates Insubmissos}

Sobre o trecho do documento que realça a necessidade de criar lideranças fortes, verificamos que ele enfatiza a necessidade de que em "cada escola exista um rosto, um primeiro responsável dotado da autoridade necessária para desenvolver o projeto educativo da escola e executar medidas de política educativa" (idem, ibidem).

A análise desse trecho revela não só a intenção de se ter na representação do diretor uma extensão do exercício do poder estatal (LIMA, 2005) como a possibilidade de responsabilizar o diretor em casos de desacordo das normas, falta de eficiência e problemas administrativos relacionados ao agrupamento. "Esse objetivo concretiza-se no presente decreto-lei pela criação do cargo de diretor, coadjuvado por um subdirector e um pequeno número de adjuntos, mas constituindo um órgão unipessoal e não um órgão colegial” (PORTUGAL, 2008, p. 2341).

Cabe ao diretor a gestão administrativa, financeira e pedagógica, porém não é mencionada no documento a dimensão política (relevante a uma gestão democrática). Reforçando o caráter centralizador, o documento indica que,

[...] no sentido de reforçar a liderança da escola e de conferir maior eficácia, mas também mais responsabilidade ao diretor, é-lhe conferido o poder de designar os responsáveis pelos departamentos curriculares, principais estruturas de coordenação e supervisão pedagógica (idem, ibidem).

No que se refere à autonomia das escolas, o Decreto-Lei ressalta que, embora sendo essa autonomia desejada por muitos, ela perdeu em retórica ao longo do tempo, alertando: "uma maior autonomia tem de corresponder a uma maior responsabilidade" (idem, ibidem), pois

A extensão da autonomia depende da dimensão e da capacidade do agrupamento de escolas ou escola não agrupada e o seu exercício supõe a prestação de contas, designadamente através dos procedimentos de auto-avaliação e de avaliação externa (idem, p. 2344).

O Decreto-Lei permite a criação de conselhos pedagógicos, mas ressalva que esses conselhos devem ser compostos por um número limitado de membros. Também se torna obrigatório que cada escola crie estruturas de coordenação (departamentos curriculares) e diretores de turmas. O funcionamento das escolas passou a associar-se ao cumprimento de regras e normas que limitam a concepção de uma gestão democrática e condicionam as escolas a uma administração estatal centralizada e pautada em avaliações externas. 


\section{Revista \\ Debates Insubmissos}

O sistema de ensino português é muito dirigista, quer dizer, centralizado. Os programas, de primeiro, eram muito homogêneos, muito bem estabelecidos, quer dizer, o professor é um aplicador dos métodos. Depois surgiu uma época de competências, onde era exigida uma lista de competências, onde cada pessoa devia procurar um método de operacionalizar aquilo, onde cada professor podia interpretar aquilo. E agora vivemos uma época de metas, onde somos obrigados a alcançar aquilo. Mas os professores foram criados naquela época, dos manuais, ou seja, padronizados, eles foram formatados pra isso, enquanto que os alunos já são de outra época (PROFESSOR DA FIGURAÇÃO SEDE, Entrevista).

$\mathrm{Na}$ fala desse professor de uma das figurações, percebemos que a análise dos processos subsequentes que envolvem as políticas públicas do campo educacional se torna relevante e nos ajuda a refletir sobre o impacto desses processos na composição das culturas escolares.

Encontramos, no Artigo $10^{\circ}$, mais algumas informações referentes ao teor dessas imposições relativas às regras que delimitam a composição do Conselho Geral. De acordo com o artigo, a composição do "Conselho Geral deve ser de número ímpar e nunca maior do que 21; que o pessoal docente e não docente não pode ser superior a 50\%; e que alunos só são admitidos no nível secundário" (PORTUGAL, p. 2345).

Identificamos uma limitação na divisão de poder, pois o Decreto limita a participação de membros do quadro docente e não docente (funcionários, pais, representantes da sociedade civil) bem como a participação dos alunos, pois estes só terão direito à representação, à participação e ao voto, caso seus representantes estejam no último nível de ensino.

Sobre as competências, o diretor deve "exercer o poder hierárquico em relação ao pessoal docente e não docente; e o poder disciplinar sobre os alunos" (idem, p. 2347). Destacamos desse trecho a importância dada aos termos "hierarquia" e "disciplina" para a constituição das relações entre diretor, docentes, não docentes, alunos, pais e demais representantes da comunidade escolar.

A influência da imposição dessa concepção nas relações socioprofissionais pôde ser confirmada por nossa pesquisa de campo, contudo os dados que apresentamos no capítulo empírico sobre o campo educacional português evidenciaram quanto a representação do diretor de todo o agrupamento modifica-se a depender da figuração onde ele se encontra.

$\mathrm{Na} F N$, o diretor sempre se valeu do uso da hierarquia e autoridade atribuídas ao seu cargo para impor suas determinações frente à insatisfação da coordenação e dos funcionários, 
mas o mesmo procedimento não se fazia necessário na FT, dado o caráter mais informal e familiar das relações socioprofissionais, tampouco, na FS, dada sua complexidade e autonomia.

Quanto aos critérios que definem a possibilidade de se ocupar o cargo de diretor, o Decreto-Lei indica que a autonomia da escola deve exprimir-se não só na faculdade de autoorganização, mas também na escolha do diretor baseada em meritocracia e na adequação a sistemas de avaliação próprios e externos. Assim, o diretor deve

[...] ser eleito pelo conselho geral; ter realizado concurso prévio; ser professor do ensino público ou privado, com pelo menos 5 anos de experiência, com qualificação em administração e gestão escolar; ter tido experiência de pelo menos um mandato como diretor ou adjunto do diretor, presidente ou vice do conselho executivo, ou diretor executivo ou adjunto do diretor executivo, ou membro do conselho diretivo (PORTUGAL, p. 2345).

Pautada em conceitos de tecnicismo, profissionalização e meritocracia, a escala de exigências a ser seguida para a ocupação do cargo de diretor, além de normatizar o preenchimento do cargo, também explica por que tantos professores acumulam funções nas figurações, conforme pudemos identificar em nossas observações.

Mesmo que a ocupação de várias funções não implique maior remuneração para os professores e ainda sobrecarregue suas rotinas de trabalho, ela se explica pela exigência de que, para tornar-se diretor, antes se tenha desempenhado essas funções.

Eu acho que nós, os professores, damos muito de nós. Mas, ao mesmo tempo, nós não temos, como poderia dizer, não recebemos o que deveríamos. Os pais depositam em nós muitas coisas que são os pais, as responsabilidades, que eles deviam ter, não é? Então, é como vos digo: não digo que a maioria, mas, se o aluno é bom é porque é inteligente, mas, se o aluno é mau, não consegue, a culpa é do professor. Aí, quando ocupamos mais de um cargo, pelo menos, isso serve como uma terapia do elogio (PROFESSOR, FS, Entrevista).

\subsection{Projeto Educativo e Figurações de Portugal}

O Projeto Educativo (PE) no campo educacional português pode ser interpretado como um instrumento normativo de controle burocrático, mas também como um instrumento viabilizador da autonomia escolar.

Isto significa que a 'autonomia da escola' é um conceito construído social e politicamente, pela interação dos diferentes atores organizacionais, numa determinada escola. Não existe autonomia decretada. O que se pode decretar são as normas e regras formais que regulam a partilha de poderes e a distribuição de competências entre os diferentes níveis de administração, incluindo o estabelecimento de ensino. Essas 


\section{Revista \\ Debates Insubmissos}

normas podem favorecer ou comprometer a autonomia da escola, mas são, só por si, incapazes de criar ou destruir a autonomia (BARROSO, 1999, p. 143).

Barroso indica que, na medida em que se constitui como um documento, ele passa a ser algo visível, tangível e, portanto, verificável. Assim, o projeto educativo serve tanto para a orientação do trabalho dos educadores quanto para a fiscalização sobre o trabalho desses profissionais por parte do Estado.

A interpretação que toma o PE como viabilizador de uma maior autonomia é corroborada por Ana Martinho. Ela entende que o projeto educativo deve indicar a identidade para a qual a comunidade educativa deve caminhar. O projeto educativo é a expressão de um agregado de vontades afinadas no seio da comunidade escolar que, por sua vez, fomenta as relações interpessoais e de responsabilização coletiva.

O projeto educativo é o documento de caráter pedagógico que, elaborado com a participação da comunidade educativa, estabelece a identidade própria de cada escola através da adequação do quadro legal à sua situação em concreto, apresenta o modelo geral da organização e os objetivos pretendidos pela instituição e, enquanto instrumento de gestão, é o ponto de referência orientador na coerência e unidade de ação educativa (MARTINHO, 2010, p. 41).

Martinho também destaca que o projeto educativo é capaz de estabelecer a identidade própria de cada escola, correlacionando sua situação particular com o contexto social e político maior. Ele pode servir como instrumento facilitador da gestão escolar e norteador daquilo que se pretende conquistar ou aonde se quer chegar. No entanto, essa autora alerta para o fato de que todas essas possibilidades precisam estar vinculadas aos anseios e envolvimento da comunidade escolar, pois, caso contrário, o PE pode funcionar apenas como um instrumento burocrático de controle.

A esse respeito, Rui Canário defende que a análise investigativa e de autogestão que se debruce sobre os processos que geram mudanças deliberadas no interior do sistema escolar devem considerar o estabelecimento de ensino como uma globalidade sistêmica. Esses estabelecimentos se constituem pela "articulação local das dimensões organizacional e pessoal, no quadro de processos instituintes de produção de inovações” (idem, 2005, p. 55).

Em outras palavras, esse autor entende que, sem essa articulação, o projeto educativo assume o simples papel de documento burocrático voltado ao cumprimento de normas. 


\section{Revista \\ Debates Insubmissos}

A construção, e o êxito, de inovações à escala do estabelecimento de ensino, com a participação dos professores, supõem a construção de um claro, e explícito, projeto educativo de escola que lhe dê sentido pleno. A articulação entre as vertentes individual e coletiva da mudança organizacional supõe a multiplicação de formas de interação social (formais e informais), em que os diversos órgãos de gestão (nomeadamente de gestão intermédia) têm um papel decisivo a cumprir (CANÁRIO, 1992, p. 71).

Em se tratando da política de Agrupamento de Escolas em Portugal, o projeto educativo do agrupamento existente é único e comum a todas as unidades escolares (grifo nosso). Destacamos essa informação pela importância que deve ter a identificação e valorização das particularidades de cada cultura organizacional escolar, algo que não ocorre quando se obriga que um mesmo projeto educativo seja comum a todas unidades de ensino.

Questionamos, então, como um único projeto educativo conseguiria contemplar as características e necessidades de cada figuração escolar. Seria ele abrangente a esse ponto ou o seu caráter de padronização se constituiria como mais uma ferramenta de controle e normatização da relação periférica estabelecida entre Estado, escola-sede e demais unidades?

\subsection{Agrupamento de Escolas}

A obrigação de que o projeto educativo sirva para todas as escolas do agrupamento nos indica quão a relevância de serem consideradas as particularidades de cada cultura organizacional é negligenciada. Nossa análise de conteúdo do Projeto Educativo indica que, em seu Índice (p. 3), não há qualquer referência específica a cada uma das organizações escolares que compõem o agrupamento, muito menos às características da cultura organizacional de cada uma delas.

No início do documento há um parágrafo que sintetiza a discussão sobre conceber o projeto educativo como instrumento normativo ou como um documento que expresse maior autonomia para o agrupamento.

O Projeto Educativo é um documento estruturante que, num quadro de democratização e de autonomia das escolas, enquanto espaço promotor de responsabilidades partilhadas, expressa princípios e valores comuns e orienta a ação educativa da Escola (Projeto Educativo, p. 4).

Notamos que a fala sobre o desenvolvimento da autonomia vem ladeada pela ideia de responsabilidade. Essa observação nos remete a um dos decretos-lei que analisamos no primeiro 
capítulo e que rege a política de agrupamentos: "a tão ansiada autonomia escolar deve corresponder a uma maior responsabilidade" (PORTUGAL, 2008, p. 2342).

Lembramos a fala de um ator quando o questionávamos sobre quanto o projeto educativo poderia ter contribuído para a autonomia da figuração escolar. Ele nos alertou para o que classifica como caráter dirigista e centralizador do governo da educação em Portugal. A lógica do agrupamento serviria como instrumento de maior controle sobre as figurações.

Depois de um período de convulsão social, a escola democratizou-se, massificou-se e portanto, o Ministério da Educação transformou-se em um monstro que perdeu um bocadinho, mas tenta recuperar o controle através dos documentos, relatórios, programas e avaliações sobre o agrupamento (PROFESSOR da FS, Entrevista).

Apenas descobrimos que havia um único projeto educativo comum a todas as figurações do agrupamento quando conversamos com outro ator social. Ao entrevistar a coordenadora da Figuração Nova e questioná-la se havia participado da elaboração do PE, ela respondeu que sim, mas quando ainda trabalhava na Figuração Tradicional.

Preocupados em saber se ela havia nos compreendido de fato, insistimos na pergunta sobre o projeto daquela figuração, onde ela trabalhava no momento. E ela reforçou a lembrança de que aquela figuração tem o mesmo projeto educativo de todo o agrupamento.

É assim: o projeto educativo é um projeto do agrupamento. Há o projeto educativo e depois há um plano anual do agrupamento, que eu até faço parte da equipe, que tem as atividades todas e é o mesmo plano anual de atividades do agrupamento. Então todo o agrupamento tem todas as atividades realizadas por todos os sítios. Desde o jardim de infância, passando por todos os ciclos e por todos os grupos que existem. E nesse documento estão todas as atividades que estão projetadas pra realizar desde o início do ano (COORDENADORA da FN, Entrevista).

Enfatizamos não só fato de o projeto ser único como também o de a coordenadora pedagógica entender essa situação como natural, mesmo depois de havermos insistido para ter acesso ao projeto específico da figuração onde ela trabalhava. Além disso, várias vezes, a coordenadora valorizou a padronização de atividades em todas as figurações do agrupamento, esquecendo-se de que as figurações escolares não são iguais.

Voltando ao documento, mesmo quando identificamos passagens que remetem à perspectiva de autonomia, notamos que elas enfatizam mais o aspecto da eficiência e do alcance de metas do que propriamente as questões pedagógicas e os processos de democratização. 


\section{Revista \\ Debates Insubmissos}

Este Projeto Educativo, com duração prevista para os próximos 3 anos, e em função do diagnóstico realizado (Análise SWOT), enquadra a sua ação no Modelo de Avaliação Externa das Escolas da IGE. São identificadas áreas de intervenção, estabelecidos objetivos, priorizadas opções estratégicas, definidas as metas a atingir e propõe-se avaliar os seus resultados em momentos diversificados: trimestralmente, anualmente e no final do ciclo trienal (Projeto Educativo).

Esses aspectos são reforçados em outros itens do PE. O item 10, Objetivos, Metas, Indicadores de Medida, Valor de partida, Valor de Chegada e Monitorização (p. 30-45) exemplifica nossa observação. Além de seu título deixar evidente o teor administrativo do item, observamos que ele se estende por 15 páginas de um total de 48 que compõem todo o projeto. Nessas 15 páginas, encontramos vários dados quantitativos expostos em tabelas e que são usados como parâmetros de comparação para o alcance de metas e resultados.

Tendo em conta o Quadro de Referência da IGE (Resultados, Prestação do Serviço Educativo e Liderança e Gestão), foi estabelecido um plano de ação contendo os seguintes parâmetros: objetivos, estratégias, metas, indicadores de medida, valor de partida, valor de chegada e monitorização (Projeto Educativo, p. 30).

Esse trecho evidencia que a perspectiva de estimular nas escolas uma maior autonomia para a elaboração e execução de suas práticas pedagógicas tem cedido espaço ao estabelecimento não só de uma perspectiva pautada no alcance de metas nos exames e avaliações como dos preceitos de racionalização e profissionalismo no sistema educacional (LIMA, 2004; GOMES, 2005 e BARROSO, 2006).

Ao analisarmos a bibliografia utilizada para elaboração do projeto educativo, percebemos que há apenas um livro de caráter acadêmico-pedagógico, cujo título é Melhorar as Escolas: Práticas eficazes (GÓIS, E. \& GONÇALVES, C., 2005). Por outro lado, as demais referências utilizadas são relatórios de avaliação, observatórios de qualidade etc.

Chama atenção uma referência cujo título é Projeto de Intervenção do Diretor do Agrupamento de Escolas (Projeto Educativo, p. 45). Em outras palavras, além do único livro de caráter mais pedagógico tratar de como tornar as escolas mais eficazes, ainda há outro que orienta a ação do diretor com caráter mais voltado à intervenção do que à participação.

Mesmo quando analisamos os itens Missão (idem, p. 18), Valores e Princípios (ibidem, p. 19), não encontramos qualquer referência à valorização das características de cada cultura organizacional escolar. Por outro lado, identificamos um diagnóstico administrativo que segue 
o modelo SWOT [Pontos Fortes (Strengths), Pontos Fracos (Weaknesses), Oportunidades (Opportunities) e Ameaças (Threats)]. Até louvamos a utilização desses procedimentos para o diagnóstico de uma gestão escolar, contudo, chama atenção o fato de essa análise não citar a valorização das características da cultura organizacional de cada figuração como uma fragilidade da atual gestão ou, ao menos, uma oportunidade. $\mathrm{O}$ único item lembrado como uma oportunidade se apresenta de maneira oposta à nossa perspectiva e reforça a centralização.

Visitas à escola-sede do agrupamento por alunos de outros ciclos de ensino e de outras escolas do agrupamento, como forma de criarem laços à "escola-mãe", para a sentirem, não como uma escola dos outros, mas sim como uma escola também sua (Projeto Educativo, p. 14).

Como já destacamos neste capítulo, devemos considerar que a maioria dos atores reinterpreta o projeto educativo de acordo com os valores da sociedade autoritária que os forjou e, dessa forma, reproduz a lógica da centralização do poder também no campo educacional. Nesse sentido, a análise dos dados da próxima tabela levará em consideração a faixa etária e o envolvimento dos atores na construção do projeto educativo do agrupamento.

Tabela 1: Relação entre participação na elaboração do PE e Faixa Etária por Figuração (Continua)

\begin{tabular}{|c|c|c|c|c|c|c|c|c|}
\hline \multicolumn{3}{|c|}{ FIGURAÇÃO } & \multicolumn{5}{|c|}{ FAIXA ETÁRIA } & \multirow[t]{2}{*}{ Total } \\
\hline & & & $25-30$ & $31-40$ & $41-50$ & $51-60$ & +60 & \\
\hline & & & 0 & 0 & & 2 & & 2 \\
\hline \multirow[t]{8}{*}{ Nova } & $\begin{array}{c}\text { VOCÊ. } \\
\text { PARTICIPOU }\end{array}$ & NÃO ASSINALOU & $0,0 \%$ & $0,0 \%$ & & $100 \%$ & & $100 \%$ \\
\hline & $\begin{array}{c}\text { ELABORAÇÃO } \\
\text { DO PE }\end{array}$ & & $0,0 \%$ & $0,0 \%$ & & $18,2 \%$ & & $18,2 \%$ \\
\hline & & & 0 & 0 & & 1 & & 1 \\
\hline & & SIM & $0,0 \%$ & $0,0 \%$ & & $100,0 \%$ & & $100 \%$ \\
\hline & & & $0,0 \%$ & $0,0 \%$ & & $9,1 \%$ & & 9,1 \\
\hline & & NÃO & 1 & 1 & & 6 & & 8 \\
\hline & & & $12,5 \%$ & $12,5 \%$ & & $75,0 \%$ & & $100 \%$ \\
\hline & & & $9,1 \%$ & $9,1 \%$ & & $54,5 \%$ & & $72,7 \%$ \\
\hline
\end{tabular}




\begin{tabular}{|c|c|c|c|c|c|c|c|c|c|}
\hline & Total & & 1 & 1 & & 9 & & 11 & \\
\hline & & & $9,1 \%$ & $9,1 \%$ & & $81,8 \%$ & & $100 \%$ & \\
\hline & & & $9,1 \%$ & $9,1 \%$ & & $81,8 \%$ & & $100 \%$ & \\
\hline & VOCÊ. & SIM & & 1 & 1 & 1 & 0 & 3 & \\
\hline Tradicional & PARTICIPOU & & & $33,3 \%$ & $33,3 \%$ & $33,3 \%$ & $0,0 \%$ & $100 \%$ & \\
\hline & ELABORAÇÃO & & & $9,1 \%$ & $9,1 \%$ & $9,1 \%$ & $0,0 \%$ & $27,3 \%$ & \\
\hline & DO PE & & & & & & & & \\
\hline & & NÃO & & 1 & 3 & 2 & 1 & 7 & \\
\hline & & & & $14,3 \%$ & $42,9 \%$ & $28,6 \%$ & $14,3 \%$ & $100 \%$ & \\
\hline & & & & $9,1 \%$ & $27,3 \%$ & $18,2 \%$ & $9,1 \%$ & $63,6 \%$ & \\
\hline & & NÃO SEI & & 0 & 1 & 0 & 0 & 1 & \\
\hline & & & & $0,0 \%$ & $100,0 \%$ & $0,0 \%$ & $0,0 \%$ & $100,0 \%$ & \\
\hline & & & & $0,0 \%$ & $9,1 \%$ & $0,0 \%$ & $0,0 \%$ & $9,1 \%$ & \\
\hline & & & & 2 & 5 & 3 & 1 & 11 & \\
\hline & Total & & & $18,2 \%$ & $45,5 \%$ & $27,3 \%$ & $9,1 \%$ & $100 \%$ & \\
\hline & & & & $18,2 \%$ & $45,5 \%$ & $27,3 \%$ & $9,1 \%$ & $100 \%$ & \\
\hline & & & & 0 & 2 & 9 & 2 & 13 & 37 \\
\hline & VOCÊ. & SIM & & $0,0 \%$ & $15,4 \%$ & $69,2 \%$ & $15,4 \%$ & $100 \%$ & \\
\hline \multirow[t]{8}{*}{ Sede } & $\begin{array}{l}\text { PARTICIPOU DA } \\
\text { ELABORAÇÃO }\end{array}$ & & & $0,0 \%$ & $5,7 \%$ & $25,7 \%$ & $5,7 \%$ & $37,1 \%$ & \\
\hline & DO PE & & & 0 & 6 & 4 & 4 & 14 & \\
\hline & & NÃO & & & & & & & \\
\hline & & & & $0,0 \%$ & $42,9 \%$ & $28,6 \%$ & $28,6 \%$ & $100 \%$ & \\
\hline & & & & $0,0 \%$ & $17,1 \%$ & $11,4 \%$ & $11,4 \%$ & $40,0 \%$ & \\
\hline & & & & 2 & 4 & 2 & 0 & 8 & \\
\hline & & $\begin{array}{c}\text { NÃO SEI } \\
\text { RESPONDER }\end{array}$ & & $25,0 \%$ & $50,0 \%$ & $25,0 \%$ & $0,0 \%$ & $100 \%$ & \\
\hline & & & & $5,7 \%$ & $11,4 \%$ & $5,7 \%$ & $0,0 \%$ & $22,9 \%$ & \\
\hline
\end{tabular}

FIGURAÇÃO

FAIXA ETÁRIA

\begin{tabular}{rrrrr}
$25-30$ & $31-40$ & $41-50$ & $51-60$ & +60 \\
\hline 2 & 12 & 15 & 6 & 35
\end{tabular}

Total

$\begin{array}{rrrrr}5,7 \% & 34,3 \% & 42,9 \% & 17,1 \% & 100 \% \\ 5,7 \% & 34,3 \% & 42,9 \% & 17,1 \% & 100 \%\end{array}$




\section{Debates Insubmissos}

Revista

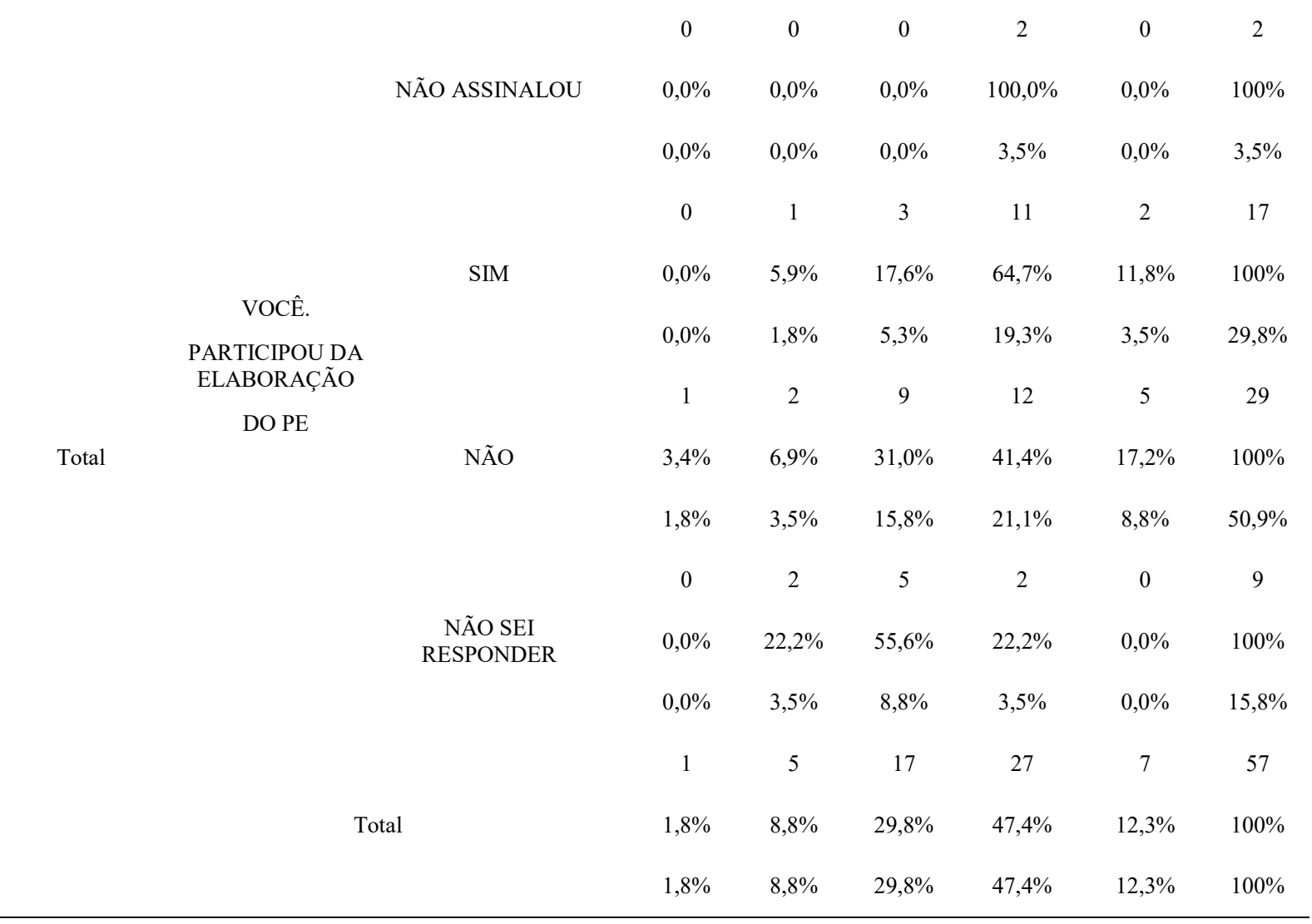

A Tabela 1 indica que $66,7 \%$ dos profissionais não participaram da elaboração do projeto educativo ou não sabem responder. Esta última categoria também foi considerada porque, na medida em que $15,8 \%$ não sabem responder, temos a indicação de que o profissional não participou da elaboração ou o fez de maneira que pouco contribuiu para que o PE servisse de orientação para as suas atividades profissionais.

49\% dos que responderam não ter participado ou disseram não saber responder se encontra na faixa etária que vai dos 41 aos 60 anos. Os representantes da faixa etária acima dos 60 anos correspondem a 8,8\% do total. Em outras palavras, a maioria dos profissionais é de indivíduos que viveram no período autoritário ou nasceram logo depois que ele acabou.

Quando estratificamos esses dados por figuração, percebemos que, na Figuração Tradicional, apenas $27,3 \%$ dos profissionais afirmaram ter participado da construção do projeto educativo. Na Figuração Nova, esse percentual cai para apenas 9,1\%. No caso da Figuração 
Sede, destacamos que $63 \%$ dos profissionais não participaram da elaboração do PE. Esse dado também é relevante pelo fato de a FS ser a principal unidade do agrupamento e gestora do PE, ou seja, responsável pela elaboração, distribuição e avaliação das práticas vinculadas a ele.

Ressaltamos que a possibilidade de construir um documento como o projeto educativo com a participação de diversos atores sequer seria considerada em sociedades autoritárias. Contudo, mesmo em uma democracia, muitos dos atores do agrupamento não se identificaram com essa construção mais participativa porque se acostumaram a apenas obedecer às ordens hierárquicas. Para esses profissionais, a prática democrática é entendida como desnecessária, pois demanda mais tempo, reuniões, debates, etc.

Tabela 2: Relação entre Frequência com a qual a escola funciona de acordo com o PE e Figuração

\begin{tabular}{|c|c|c|c|c|c|c|}
\hline FIGURAÇÃO & $\begin{array}{c}\text { Não } \\
\text { Assinalou }\end{array}$ & Nenhuma & Raramente & Frequentemente & Sempre & Total \\
\hline \multirow[b]{2}{*}{ Nova } & 0 & 0 & 0 & 9 & 2 & 11 \\
\hline & $0,0 \%$ & $0,0 \%$ & $0,0 \%$ & $15,8 \%$ & $3,5 \%$ & $19,3 \%$ \\
\hline \multirow{2}{*}{ Tradicional } & 0 & 1 & 1 & 8 & 1 & 11 \\
\hline & $0,0 \%$ & $1,8 \%$ & $1,8 \%$ & $14,0 \%$ & $1,8 \%$ & $19,3 \%$ \\
\hline \multirow{2}{*}{ Sede } & 2 & 2 & 2 & 19 & 10 & 35 \\
\hline & $3,5 \%$ & $3,5 \%$ & $3,5 \%$ & $33,3 \%$ & $17,5 \%$ & $61,4 \%$ \\
\hline \multirow{2}{*}{ Total } & 2 & 3 & 3 & 36 & 13 & 57 \\
\hline & $3,5 \%$ & $5,3 \%$ & $5,3 \%$ & $63,2 \%$ & $22,8 \%$ & $100 \%$ \\
\hline
\end{tabular}

Fonte: Questionários da Pesquisa de Campo

Na Tabela 2, verificamos que $86 \%$ de todos os profissionais do agrupamento afirmam que a figuração na qual trabalham funciona frequentemente e sempre de acordo com o projeto educativo. Essa impressão de que a figuração funciona de acordo com o que é estabelecido pelo 
projeto educativo é significativamente maior do que quando os atores foram questionados sobre a participação deles na elaboração do projeto $(29,8 \%)$.

Na Figuração Sede, apenas 7\% dos profissionais entendem que a frequência com a qual a figuração funciona de acordo com o PE é nenhuma ou não responderam. Na Figuração Tradicional, o percentual dos que acham que ela funciona com nenhuma frequência diminui para apenas $1,8 \%$, enquanto que, na FN, nenhum dos profissionais assinalou essas opções.

É significativa, então, a diferença entre obedecer às regras do projeto educativo e participar da elaboração dele, pois, enquanto $86 \%$ dos entrevistados entendem que a figuração funciona de acordo com o que determina o documento, apenas $29,8 \%$ dizem ter participado da elaboração dele. Isso nos leva a constatar que o incentivo à participação na gestão escolar ainda não foi alcançado pelas figurações que compõem o agrupamento escolar em análise.

Além disso, na medida em que não faz qualquer referência à identificação das características de cada cultura escolar e à valorização delas, o PE do agrupamento não viabiliza a autonomia de cada figuração e corrobora o caráter de normatização e padronização de atividades imposto pelo governo da educação ao campo educacional português.

\section{ALGUMAS CONSIDERAÇÕES}

A constatação de que cada escola constitui uma cultura organizacional única está longe de ser considerada pelos agentes responsáveis pela elaboração e implementação de políticas públicas. Essa percepção costuma ser comungada por poucos, a exemplo de profissionais que já trabalharam em mais de uma escola e que, consequentemente, foram levados a conviver com culturas organizacionais diferentes.

Apesar disso, verificamos quanto as políticas públicas têm a sua viabilização diretamente ligada às formas como elas são apropriadas e dinamizadas em cada cultura organizacional escolar. Uma das principais constatações da nossa pesquisa foi perceber como sociedades que foram governadas por regimes autoritários ainda tinham muitas das características desses regimes presentes na cultura das organizações do campo educacional. 


\section{Revista \\ Debates Insubmissos}

Notamos que Portugal iniciou seu processo de redemocratização na década de 1970 e que os princípios propagados por esses processos passaram a ser incorporados também pela área da educação. Exemplo é a implementação da política de Gestão Democrática da Educação.

Verificamos, contudo, que a viabilidade dessa política foi ameaçada pelos processos subsequentes que envolvem a sua implementação. Diante das realidades já sedimentadas nas organizações do campo educacional, a política de gestão democrática da educação foi sendo gradativamente influenciada por processos que deram margem à implementação da política de de Agrupamento de Escolas em Portugal.

$\mathrm{Na}$ medida em que ela procura agregar distintas escolas em torno da administração centralizada de uma única escola-sede, tal política termina por tomar as distintas realidades de cada escola do agrupamento como se elas fossem padronizadas e homogêneas, ou seja, não leva em conta as particularidades da cultura organizacional de cada uma delas.

A implementação dessa política fez os objetivos pretendidos pela política de gestão democrática da educação não serem alcançados por todas as organizações escolares. Por mais propositivos que fossem seus objetivos, seus princípios foram sendo superados pelo desencadear de seus processos subsequentes e pelos difusos interesses dos agentes governamentais que se alternaram no controle do Estado.

A respeito das organizações escolares pesquisadas, verificamos que elas ainda compartilham culturas organizacionais que mesclam tardias práticas socioprofissionais herdadas dos regimes autoritários com novas demandas sociais influenciadas pela redemocratização. Nesse sentido, a viabilização da política de gestão democrática da educação, da forma como foi apropriada pelas interpretações e práticas de muitos dos atores sociais, pode em muito ser influenciada pela prática de gestão dos diretores escolares.

Assim, se o diretor apresentasse disposição para gerir a organização escolar de maneira democrática e não encontrasse forte resistência a isso, ele conseguiria desenvolver importantes princípios da política. Já se o diretor não tivesse essa postura e também não fosse cobrado pelos atores para que a desenvolvesse, a tendência seria que ele viesse a se valer dessas condições para desenvolver uma gestão escolar centralizada. 
De toda forma, validamos a orientação de realizar-se uma análise sociológica da organização escolar que considere a premissa de que ela se encontra inserida em um contexto no qual sofre influência do nível macro, representado pela estrutura estatal ao qual a escola está submetida, e do nível micro, representado pela ação dos atores que a compõem.

As evidências encontradas por nossa pesquisa empírica nos remeteram à sociologia de Norbert Elias, segundo o qual apenas após a passagem de acontecimentos que envolvam duas ou três gerações é que podemos perceber processos efetivos de mudança social. Ao recorrermos à sociologia processual eliasiana, percebemos que ainda há um ranço comportamental não democrático nas culturas das organizações escolares dos dois campos educacionais, o qual influencia o processo de apropriação e viabilização de políticas públicas.

Como esse campo educacional ainda se encontra no início da segunda geração influenciada pela implementação da política de gestão democrática da educação, percebemos que a mudança social esperada a partir da sua implementação ainda não se manifesta nas práticas socioprofissionais da maioria dos atores.

No caso de Portugal, investigamos três figurações de um mesmo agrupamento de escolas. A partir dessa investigação, confirmamos a hipótese de que a política de agrupamentos não só limita a autonomia e gestão democrática das escolas como também as condiciona a uma situação periférica dentro do próprio agrupamento em relação à escola-sede, incluindo para excluir. Centro da administração do agrupamento, a escola-sede beneficia-se dos principais recursos humanos e materiais do agrupamento, centralizando as práticas de gestão das unidades.

Essa concentração de recursos educativos facilita a gestão da escola-sede, caracterizando-a como a figuração do agrupamento onde mais se desenvolvem princípios de autonomia e participação (heranças da política de gestão democrática). Assim, nela se concentram as atividades de elaboração de documentos, como o projeto educativo, e as reuniões dos representantes de todas as escolas do agrupamento, por exemplo.

Contudo, essa concentração de recursos educativos na escola-sede implica incongruência no processo de gestão das demais escolas, pois não permite que elas desenvolvam sua autonomia e participação, condicionando-as a uma atuação coadjuvante e 


\section{Revista \\ Debates Insubmissos}

periférica quanto à gestão do agrupamento. Em nossa pesquisa, refutamos o argumento estatal de que, por tratar-se de uma política pública propositiva, a política de agrupamentos garantiria maior visibilidade às escolas que se encontravam em algum grau de isolamento e distanciamento do Estado.

Além disso, percebemos que essa política não permite ao diretor do agrupamento desenvolver práticas de gestão condizentes com as características que compõem a cultura organizacional de cada escola. A nossa análise de conteúdo do projeto educativo nos levou a identificar a determinação estatal de que o projeto seja um documento único e comum a todas as escolas do agrupamento. Aliás, a análise de conteúdos dos projetos pedagógicos elaborados pelas figurações escolares dos dois campos educacionais revelou que tais documentos não conferiram a atenção necessária à importância de identificarem-se e valorizarem-se as caracterísitcas que compõem cada cultura organizacional.

A possibilidade de que cada escola elabore seu próprio projeto pedagógico é vista como importante passo para o reconhecimento e valorização das características de cada cultura organizacional. Contudo, percebemos ser comum que os projetos representem apenas um documento exigido pelos órgãos educacionais, e não um instrumento de ações voltadas à valorização das caracterísiticas de suas comunidades escolares, dependendo dos atores que elaboraram os projetos, bem como da maneira como eles são utilizados.

Também realizamos a mesma análise do conteúdo dos documentos estatais responsáveis por informar os atores sociais sobre as políticas públicas e as determinações atribuídas ao campo educacional. Nessa análise constatamos que o tema gestão democrática da educação foi sendo gradativamente superado por novas orientações.

No caso dos documentos do campo educacional português, percebemos, por exemplo, que a expressão "autonomia escolar" é confundida com falta de responsabilidade e ausência de prestação de contas. Constatamos que os documentos estatais não representam os avanços ansiados pela política de gestão democrática da educação, tampouco revelam preocupação em identificar e valorizar a cultura organizacional de cada escola. Consideramos essa constatação 
relevante por entendermos que, diferentemente de organizações empresariais, a administração padronizada de organizações escolares é incongruente com as suas particularidades.

A partir da etnografia, percebemos que questões ligadas à comunicação entre os órgãos estatais e as organizações escolares se mostraram difusas e passíveis de interpretações não congruentes. Notamos, ainda, que os atores sociais das escolas não comungavam de um mesmo entendimento sobre o que define as políticas públicas, seja quanto ao conhecimento dos seus objetivos, seja em relação às melhorias que elas podem trazer às atividades da escola.

A análise das atividades cotidianas evidenciou as diferentes (re)interpretações de uma mesma política por parte dos atores das escolas. Maior exemplo dessa diversidade de interpretações é o pouco conhecimento sobre o conteúdo dos projetos pedagógicos por parte dos atores bem como a pequena participação deles na elaboração desses documentos.

Isso também se reflete na percepção que os atores têm da própria participação na gestão escolar. As percepções dos atores sobre participação na gestão e autonomia profissional são influenciadas pela compreensão de que suas atividades se restringem a um trabalho burocrático e voltado ao alcance de resultados em sistemas de avaliação externos.

\section{REFERÊNCIAS}

AFONSO, Natércio. A direção Regional de Educação: um espaço de regulação intermédia. In: BARROSO, João. A regulação das políticas públicas em educação. Coimbra, 2006.

ALMEIDA, Alberto. O céu era o limite!: de agrupamento Escolas Fernando Magno. Coimbra: Imprensa da Universidade, 2010.

BARROSO, João. A regulação das políticas públicas em educação. Coimbra, 2006.

BARROSO, João (org.). A regulação das políticas públicas de educação. Espaços, dinâmicas e atores. Coimbra, 2006.

BAUER, Martin \& JOVCHELOVITCH, Sandra. Entrevista narrativa e Entrevista Episódica. In BAUER, M.W. \& GASKELL, G. (orgs.). Pesquisa qualitativa com texto, imagem e som. Petrópolis, Vozes, pp.90-136, 2002. 
CORREIA, José Alfredo. As ideologias educativas em Portugal nos últimos 25 anos, p. 83110, Universidade do Minho, Braga: IEP, 1999.

DUPUIS, Jean P. Antropologia, cultura e organização: proposta de um modelo construtivista. In: CHANLAT, J. F. (Org.). O indivíduo nas organizações: dimensões esquecidas. São Paulo: Atlas, 2010. v.3. p. 231-252.

ELIAS, Norbert. A sociedade dos indivíduos. Rio de Janeiro: Zahar, 1994.

ELIAS, Norbert. Escritos e Ensaios. Rio de Janeiro: Zahar, 2006.

GILL, Rosalind. Análise de discurso. In GASKELL, George e BAUER, Martin W. Pesquisa qualitativa com texto, imagem e som. Um manual prático. Petrópolis: Vozes, 2005.

GOMES, Rui. Culturas de escola e identidades dos professores. Lisboa: Educa, 1993.

GOMES, Rui. A globalização da escola de massas. Revista Crítica de Ciências Sociais, n. 61, 2001, p. 135-168.

GOMES, Rui. O governo da educação em Portugal. Coimbra: Imprensa da Universidade, 2005.

LIMA, LICÍNIO. Agrupamento de escolas como novo escalão da administração desconcentrada. de Revista Portuguesa Educação, vol. 17, núm. 2, 2004, pp. 7-47.

MARTINHO, Ana P. F. Clima organizacional, participação e integração dos professores do $1 .^{\circ}$ ciclo do ensino básico nos agrupamentos de escolas. 2010. Dissertação (Mestrado)Faculdade de Psicologia e de Ciências da Educação. Universidade de Coimbra. Coimbra, 2010.

OLIVEIRA, Roberto C. Caminhos da Identidade: ensaios sobre etnicidade e multiculturalismo. São Paulo: Unesp, 2006.

PORTUGAL. Decreto-Lei n. 75/2008 de 22 de Abril de 2008. Ministério da Educação. Diário da República. Lisboa, $1^{\mathrm{a}}$ série, n. 79, de 22 de Abril de 2008, p. 2341 a 2356.

SCHEIN, Edgar. Organizational culture and leadership. 3 ed. San Francisco: Jossey Bass, 2004.

WEBER, Silke. Políticas do ensino fundamental em revista: um debate pela democracia. In: A.O. COSTA (org.). Uma história para contar: a pesquisa na Fundação Carlos Chagas. São Paulo: Anablume, p. 57-90, 2004.

Submetido em: 31/07/2019

Aprovado em: 24/11/2019 